\title{
Karjatilan nurmirehun korjuuaikastrategiat
}

\author{
Auvo Sairanen, Perttu Virkajärvi ja Elina Juutinen \\ MTT Kotieläintuotannontutkimus, Halolantie 31 A, 71750 Maaninka, etunimi.sukunimi@mtt.fi
}

\section{Tiivistelmä}

Säilörehu on merkittävin yksittäinen kustannuserä maidon tuotantokustannuksesta. Avaintekijä säilörehun tuotantokustannuksen alentamiseen on satotason nostaminen. Yksi keino tähän on korjata rehu nykyisiä suosituksia myöhemmin. Ensimmäisen rehunkorjuun myöhästyttäminen heikentää pääsadon rehuarvoa ja vaikuttaa seuraavan sadon määrään ja laatuun. Lisäksi säilörehun laadun muutokset vaikuttavat lehmien lisäväkirehuruokintaan, joten kokonaisuuden hallinta on vaativa tehtävä.

Korjuuaikastrategioiden tutkimiseksi MTT järjestää kolmevuotisen kehittämishankkeen (Karjatilan kannattava peltoviljely, KARPE), jossa koeruutumittakaavassa mitataan eri korjuuaikastrategioiden tuottama kokonaissato koko kasvukautta kohden. Koeruutujen lisäksi vastaavat korjuuajat toteutetaan maatilamittakaavassa, jotta saadaan tarvittava säilörehumäärä lypsylehmien ruokintakoetta varten. Hankkeen tulosten perusteella luodaan lineaarinen optimointimalli, joka kertoo taloudellisesti kannattavimman vaihtoehdon ottaen huomioon kolme eri peltoala/eläinmäärä -suhdetta. Tutkimukseen valittujen korjuuaikastrategioiden niittoajat ovat seuraavat: A) tavanomainen kahden niiton säilörehunkorjuu, jossa D-arvotavoite ensimmäisessä niitossa on $690 \mathrm{~g} / \mathrm{kg} \mathrm{ka}, \mathrm{B}$ ) myöhästetty kahden niiton rehunkorjuu, jossa ensimmäisen niiton D-arvotavoite on $650 \mathrm{~g} / \mathrm{kg} \mathrm{ka}, \mathrm{C}$ ) heinäkuun alkuun myöhästetty kahden niiton korjuustrategia, jossa ensimmäisen niiton säilörehun D-arvotavoite on $620 \mathrm{~g} / \mathrm{kg}$ ka sekä D) kolmen niiton strategia, jossa ensimmäinen korjuun D-arvotavoite on $690 \mathrm{~g} / \mathrm{kg} \mathrm{ka}$.

Kesällä 2008 tehtiin lypsylehmillä pilottikoe täydentäen D-arvoltaan 650 g/kg ka ja 690 g/kg ka säilörehuja kahdella eri väkirehutasolla (9 ja 12 kg) ja kolmella raakavalkuaistasolla (raakavalkuainen 140, 180 ja 210 g/kg ka). Ruokintakokeen perusteella 3 kg väkirehua vastasi 4 prosenttiyksikön muutosta D-arvossa mikä vastaa aikaisempia koetuloksia. Suurin maitotuotos saavutettiin D-arvoltaan 690 g/kg ka säilörehulla ja korkeimmalla väkirehutasolla. Koeasetelma ei ota kantaa siihen, miten korkea väkirehumäärä tarvittaisiin syötettäessä D-arvoltaan $650 \mathrm{~g} / \mathrm{kg}$ ka säilörehua, jotta päästäisiin samaan tuotostasoon D-arvoltaan 690 g/kg ka ja 12 kilon väkirehuyhdistelmän kanssa. Tämän kokeen perusteella väkirehussa voidaan käyttää samaa valkuaispitoisuutta säilörehun sulavuudesta riippumatta. Maitotuotos lisääntyi lineaarisesti korkeimmalle väkirehun lisävalkuaistasolle saakka. Mikäli tarkastelu rajoitetaan kokeen mukaisiin säilö- ja väkirehuihin eikä huomioida pellonkäyttöä, on D-arvoltaan 690 g/kg ka säilörehu tuottavin valinta.

Kesällä 2009 tehdyn ruutukokeen perusteella säilörehun ensimmäisen korjuuajan myöhästyttäminen lisäsi sekä kuiva-aine-, että rehuyksikkömäärää koko kesä huomioiden. Ensimmäisessä sadossa saavutettu kuiva-aineen lisäkasvu kompensoitui osittain toisessa sadossa, joten erot eri niittostrategioiden välillä eivät muodostuneet mittaviksi. Rehuyksikköarvo huomioiden erot eri niittostrategioiden välillä vielä pienenivät. Kolmen niiton strategialla kokonaissato jäi pienimmäksi. Niiton myöhästyttäminen pääsääntöisesti paransi jälkisadon sulavuutta, joten kun niittoajankohtaa muutetaan, on mahdollista säädellä kokonaissadon nurmen sulavuutta. Ruutukokeen perusteella myöhäisin ensimmäinen niitto olisi paras vaihtoehto ry-sadon perusteella.

Maatila joutuu tekemään rehuntuotantoratkaisunsa tilasysteemitasoisena, joten yksittäiset koetulokset eivät anna vastausta, mikä olisi paras vaihtoehto. Tätä varten koesarjaa jatketaan ja tiedoista muodostetaan yhdessä aikaisemman tiedon kanssa optimaalista kokonaisratkaisua hakeva malli.

Asiasanat: D-arvo, sulavuus, sato, maidontuotanto, säilörehu, nurmet, timotei, nurminata, väkirehut 


\section{Johdanto}

Karjatiloilla rehukustannus muodostaa jopa yli 50 \% kokonaiskustannuksista. Lypsylehmän rehunkulutuksesta säilörehun osuus on noin $55 \%$, eli säilörehu on merkittävin yksittäinen kustannuserä maidon tuotantokustannuksesta (ProRehustus Tuotosseuranta 2008). Avaintekijä säilörehun tuotantokustannuksen alentamiseen on satotason nostaminen. Yksi keino tähän on korjata rehu nykyisiä suosituksia myöhemmin. Ensimmäisen rehunkorjuun myöhästyttäminen heikentää pääsadon rehuarvoa ja vaikuttaa seuraavan sadon määrään ja laatuun. Lisäksi säilörehun laadun muutokset vaikuttavat lehmien lisäväkirehuruokintaan, joten kokonaisuuden hallinta on vaativa tehtävä.

Artturi ${ }^{\circledR}$-korjuuaikapalvelu suosittelee korjaamaan säilörehun D-arvon ollessa 680 - 700 g/kg ka, jos nurmiala ei rajoita maidontuotantoa. Riippuen kuitenkin maatilan yksilöllisistä eroista, kuten eläinten määrästä ja käytössä olevasta peltopinta-alasta, saattaa olla kuitenkin kannattavampaa korjata säilörehu myöhemmin ja korvata heikommin sulava säilörehu suuremmalla väkirehumäärällä (Wathén ym. 2008). Väkirehun määrän nosto tuo kuitenkin mukanaan omat vaikutuksensa niin talouden kuin eläinruokinnan kannalta tarkasteltuna. Lisääntynyt eläinmäärä hehtaaria kohden lisää lannan levityksen tarvetta.

Tyypillisessä kahden korjuukerran strategiassa sadonkorjuu tehdään päämaidontuotantoalueella heti kesäkuun puolivälin jälkeen ja toinen korjuukerta on elokuun alkupuolella. Elokuun loppua kohti mentäessä nurmisato ei enää lisäänny, koska kasvin alaosien lehdistö kuolee sitä mukaa kuin ylemmät lehtikerrokset muodostuvat. Tämä johtaa siihen, että elokuun kasvukautta ei aina pystytä hyödyntämään täysimääräisesti hyväksi. Sekä myöhästetyssä, että kolmen korjuukerran strategiassa elokuun lisäkasvu saadaan hyödynnettyä paremmin verrattuna aikaiseen korjuustrategiaan. Haittana myöhästetyssä strategiassa on ensimmäisen niiton osalta rehun heikentynyt sulavuus ja kolmen korjuun strategiassa viimeisen niiton pieni sato. Kolmen niiton strategiassa työkustannus rehuyksikköä kohti nousee suuremmaksi kahteen niittokertaan verrattuna.

Korjuuaikastrategioiden tutkimiseksi MTT järjestää kolmevuotisen kehittämishankkeen (KARPE), jossa koeruutumittakaavassa mitataan eri korjuuaikastrategioiden tuottama kokonaissato koko kasvukautta kohden. Rehuraisio Oy toimii hankkeen yhteistyökumppanina. Koepaikkoina on Maaninka ja Ruukki. Koeruutujen lisäksi vastaavat korjuuajat toteutetaan maatilamittakaavassa, jotta saadaan tarvittava säilörehumäärä lypsylehmien ruokintakoetta varten. Aineistoa käytetään hyväksi luotaessa lineaarisella optimoinnilla talousmalli, joka huomioi eri koruuaikastrategioiden suhteelliset kannattavuuserot. Tässä artikkelissa käsitellään hankkeen ensimmäisiä alustavia tuloksia Maaningan osalta.

\section{Aineistot ja menetelmät}

Tutkimukseen valittujen korjuuaikastrategioiden niittoajat ovat seuraavat:

A. Tavanomainen säilörehunkorjuu kahdella niitolla. Ensimmäinen niitto, kun säilörehun Darvo on $690 \mathrm{~g} / \mathrm{kg}$ ka ja toinen elokuun alussa, kun toisen sadon nettokasvua ei enää ole odotettavissa.

B. Myöhästetty rehunkorjuu, jossa ensimmäinen niitto on kesäkuun loppupuolella, säilörehun D-arvo 650 g/kg ka. Toinen niitto on elokuun puolivälissä.

C. Heinäkuun alkuun myöhästetty niitto, jonka säilörehun D-arvotavoite on 620 g/kg ka. Toinen niitto on elokuun lopussa.

D. Kolmen niittokerran säilörehunkorjuu, jossa ensimmäinen niitto, kun säilörehun D-arvo 690 $\mathrm{g} / \mathrm{kg}$ ka, toinen rehunkorjuu aivan heinäkuun lopussa ja viimeinen lokakuun alussa.

Kesän lämpötila/sadesumma -olosuhteet vaikuttavat korjuuhetken säilörehun sulavuuteen, samoin toistona olevan peltolohkon mikroilmasto ja maaperä. Lisäksi sade voi siirtää koeasetelman mukaisen korjuuaikatavoitteen myöhäisemmäksi. Näiden seikkojen vuoksi tavoitteiden mukaisten säilörehujen saaminen on haastava tehtävä ja tutkimus toteutettiin kahdessa mittakaavassa: maatilakokeena ja ruutukokeena. Koeruuduista pystyttiin tekemään myös sadon määrää ja laatua selittäviä havaintoja, kuten kasvuston kehitysvaihe, lakoisuus, lehtien, korsien ja kuolleen solukon osuus sadossa.

\section{Maatilamittakaava}

Hanke on alkanut vuonna 2009, mutta ensimmäinen maatilamittakaavan pilottikoe ja vastaava lehmien ruokintakoe tehtiin kesän 2008 rehunteosta MTT Maaningalla. Korjuuaikastrategioiden mukaiset niitot 
tehdään samanaikaisesti sekä maatila-, että koeruutumittakaavassa. Maatilamittakaavan koesarjassa kaikille strategioille on kolme toistoa, joista kunkin koejäsenen pinta-ala vaihtelee välillä 0,6 - 1,6 ha.

Vuonna 2008 rehut tehtiin edellisenä vuonna perustetusta timotei-nurminata kasvustosta. Kaikki sadot lannoitettiin maatalouden ympäristötuen ehtojen mukaisesti. Kesällä 2008 ensimmäisen niiton ajankohtia oli vain kaksi. Rehut niitettiin noin 10 - 12 cm:n sänkikorkeuteen. Rehuja esikuivattiin keskimäärin 24 tuntia. Säilöntäaineena käytettiin 5 l/tonni muurahaishappopohjaista AIV® 2Plus säilöntäainetta. Ensimmäisen sadon rehut säilöttiin salvosiiloihin ja toisen sadon rehut pyöröpaaleihin. Rehunäytteet otettiin silputusta rehusta erikseen jokaiselta lohkolta ja käsittelyltä jokaisesta kuormasta ja paaleista koejäsenittäin ja lohkoittain. Näytteet kuivattiin $+60^{\circ} \mathrm{C}: \mathrm{ssa} 48$ tunnin ajan ja analysoitiin NIR menetelmällä (Valio Oy).

Maatilamittakaavan rehut vuonna 2009 tehtiin pyöröpaaleihin samoilta lohkoilta kuin vuonna 2008 ja lisäksi vertailussa oli mukana vuonna 2008 perustettu timotei-nurminata-puna-apilaseos ilman toistoja. Lannoitus tehtiin nurmikasvustoille ympäristötuen ehtojenmukaisesti. Apilaseosta ei lannoitettu. Rehut niitettiin ja rehuja esikuivattiin 24 - 48 tuntia riippuen ilman kosteudesta. Puna-apilaseos niitettiin samaan aikaan koejäsenten B ja C kanssa. Säilöntäaineena käytettiin muurahaishappopohjaista AIV® Ässä säilöntäainetta 5 l/tonni. Aikaisen ja kolmen niittokerran pääsadon korjuuaikana satoi vettä, joten rehut säilöttiin salvosiiloihin. Muiden korjuukertojen rehut tehtiin pyöröpaaleihin. Näytteet rehuista otettiin kairaamalla paaleista lohkoittain ja koejäsenittäin sekä salvosiiloon tehdystä rehusta kuormittain.

\section{Ruutukokeet}

Ruutukokeet niitettiin pääsääntöisesti samana päivänä (+- 1 pv) kuin tilamittakaavan rehut. Koe perustettiin satunnaistettujen lohkojen kokeena, jossa oli neljä käsittelyä ja 3 kerrannetta. Koeruutujen koko oli 8 x 1,5 metriä. Ruudut oli perustettu 27.8.2008 siemenseoksella, joka sisälsi painoprosentteina 54 \% Tuure-timoteita ja 46 \% Ilmari-nurminataa. Ruutukokeessa ei ollut mukana apilakasvustoa. Vuotuislannoituksena annettiin koejäsenille A-C $100+100 \mathrm{~kg} / \mathrm{ha} \mathrm{N}$ ja koejäsenelle $\mathrm{D} 100+100+50$ $\mathrm{kg} / \mathrm{ha} \mathrm{N}$ sekä suositusten mukaiset määrät kaliumia ja fosforia.

Ruuduilta havainnoitiin kevättiheys, ja ennen niittoa havainnoitiin kasvuston korkeus ja lako \%. Kasvuton kehitysvaihe määritettiin Simon \& Park (1981) asteikolla leikkaamalla ruudulta maanpinnasta $0 \mathrm{~cm}$ sänkikorkeuteen neljästä kohdasta a' 10 versoa/kasvilaji tuppaasta tai laikusta, jolloin näyte sisälsi sekä pää- että sivuversoja. Sadon fraktiointia varten otettiin jokaisesta ruudusta ennen niittoa kehikkonäyte ( 20 x $50 \mathrm{~cm}$ ), josta määritettiin kuollut solukko (irtonainen kuollut ja lehtiin kiinnittynyt kuollut), lehdet (so lehtilapa), korret (ja lehtitupet) ja kukinnot. Fraktioiden tuoremassat punnittiin. Kaikki fraktiot kuivattiin $+60{ }^{\circ} \mathrm{C}$ :ssa 40 tunnin ajan ja niiden kuiva-ainemassat määritettiin. Niiton yhteydessä punnittiin ruutusato ja ruudulta otettiin kokonaisnäyte, josta analysoitiin MTT:n eläinravitsemuslaboratoriossa orgaaninen aine, orgaanisen aineen sellulaasiliukoisuus, raakavalkuainen, NDF-kuitu, ligniini, sekä pääkivennäiset ja hivenravinteet standardimenetelmin. Sulamaton kuitu (iNDF) määritettiin 12 vrk:n pötsi-inkubaatiolla nailonpusseissa karkearehuvaltaisella ruokinnalla olevia lehmiä käyttäen.

\section{Maidontuotantokoe}

Lehmien ruokintakokeessa vuoden 2008 ensimmäisen sadonkorjuun säilörehuja, D-arvoltaan 650 ja 690 g/kg ka, täydennettiin kahdella väkirehu- (9 ja 12 kg/pv) ja kolmella lisävalkuaistasolla (rv 140, 180 ja 210 g/kg ka). Ruokintakoesarjaa jatketaan kolmella lisäaloituksella vuoteen 2011 saakka. Rehuraisio toimii ruokintakokeissa yhteistyökumppanina. Yksittäiset ruokintakokeiden tulokset yhdistetään hankkeen lopussa yhdeksi laskentakokonaisuudeksi.

Kokeessa oli 36 useasti poikinutta Holstein-lehmää, joiden poikimisesta oli kulunut keskimäärin 182 päivää ja 6 ensikkoa, joiden poikimisesta oli kulunut keskimäärin 110 päivää. Lehmien keskituotos oli 33,2 kg ja ensikoiden 30,7 kg. Useasti poikineet lehmät oli jaettu 12 lehmän blokkeihin (3 kpl) maitotuotoksen ja laktaatiokauden mukaan ja käsittelyt oli arvottu satunnaisessa järjestyksessä blokkeihin. Ensikot muodostivat muodostivat oman blokin. Koe tehtiin kolmijaksoisena 2x2x3 crossover -koeasetelmana, jossa oli kaksi erilaista säilörehua (D-arvo 650 ja $690 \mathrm{~g} / \mathrm{kg} \mathrm{ka}$ ) ja raakavalkuaispitoisuudeltaan kolme erilaista teollista väkirehua (140, 180 ja 210 g/kg ka), jotka syötettiin 
lehmille kahtena eri tasona (9 ja 12 kg). Ensikot saivat ainoastaan 9 kg väkirehua. Kolmen viikon mittaisia koejaksoja oli kolme, joiden viimeisen viikon keskiarvoja käytettiin tilastoanalyysissä.

Säilörehua annettiin vapaasti, siten että jätettä jäi noin $10 \%$ annetusta määrästä. Väkirehu annettiin neljä kertaa päivässä. Maitotuotos ja syönti mitattiin jokaiselta lehmältä päivittäin. Maitonäytteet otettiin aamu -ja iltalypsyn aikaan kolmena peräkkäisenä päivänä keruukaudella. Lehmät punnittiin kokeen alussa ja jokaisen jakson lopussa.

Kuiva-aine ja pH määritettiin säilörehusta viikoittain ja kolme kertaa keruujakson aikana. Rehunäytteet otettiin säilörehusta viitenä peräkkäisenä päivänä keruujakson aikana. Näytteet pakastettiin ja kuivattiin kemiallista analysointia varten. Säilörehusta määritettiin kuiva-aine, orgaaninen aine, neutraalidetergenttikuitu ja in vitro -sellulaasimenetelmällä orgaanisen aineen sulavuus. Väkirehunäytteet otettiin samalla tavoin kuin säilörehunäytteet, mutta eri jaksojen väkirehunäytteet yhdistettiin kokeen lopussa. Näytteestä analysoitiin kuiva-aine, tuhka, raaka-valkuainen ja neutraalidetergenttikuitu. Näytteiden analysointi tehtiin MTT:n eläinravitsemuksen laboratoriossa.

\section{Tilastolliset analyysit}

Ruutukokeen tulokset analysoitiin varianssianalyysillä (ANOVA) käyttäen SAS:n Mixed- proseduuria. Ruutukokeen tulokset analysoitiin niitoittain koejäsen kiinteänä tekijänä ja kerranne satunnaistekijänä. Keskiarvoja verrattiin Tukey'n testillä. Koska kolmas niitto tehtiin vain yhdelle koejäsenelle, sen osalta ilmoitetaan vain käsittelykeskiarvot ja niiden keskivirheet. Maidontuotantokokeen tulokset testattiin SAS Mixedillä. Mallissa oli seuraavat tekijät: jakso, väkirehun raaka-valkuaispitoisuus, säilörehun sulavuus, blokki, väkirehun määrä, väkirehun määrä x säilörehun sulavuus yhdysvaikutus sekä väkirehun raakavalkuaispitoisuus x säilörehun sulavuus yhdysvaikutus. Valkuaisen osalta vasteet jaettiin lineaariselle ja quadraattiselle kontrastille.

\section{Tulokset ja tulosten tarkastelu \\ Ruutukoe}

Koska syksyn 2008 kylvöpäivän jälkeen oli varsin viileää, jäi koeruutujen oras pieneksi, mikä hidasti kevään 2009 nurmen kehitystä. Ensimmäisenä niittopäivänä sato olikin melko pieni ja vastaavasti ruohon D-arvo oli tavoitetta korkeampi. Tämän jälkeen sadon määrä nousi lineaarisesti $210 \mathrm{~kg}$ ka/ha/vrk ja 155 ry/ha'vrk (Taulukko 1). Samalla D-arvo pieneni noin 7 g/kg ka/vrk, mitä voi pitää hieman tavallista nopeampana (Rinne 2000). Viimeisenä niittoaikana ruohon D-arvo oli laskenut tavoitteen mukaiselle tasolle $600 \mathrm{~g} / \mathrm{kg}$ ka. Ry-sato siis nousi noin 250 ry ha, kun D-arvon laski $10 \mathrm{~g} / \mathrm{kg}$ ka/vrk. Kuolleen materiaalin osuus oli hyvin pieni ensimmäisessä niitossa mukaan lukien myöhäisin niittoaika.

Toisessa niitossa sadon lisäys ei ollut enää lineaarinen, vaan A koejäsenen elokuussa tehty toinen niitto tuotti selvästi suurimman sadon. Sen sijaan kolmen niiton systeemissä toinen sato jäi pieneksi, koska niitto tehtiin jo heinäkuun lopussa. Jokaisen koejäsenen D-arvot olivat kohtalaisen korkeita, vaikka nyt sato sisälsi myös kuollutta materiaalia (poislukien koejäsen D) ja korsienkin osuus oli tuntuva (poislukien koejäsen C). Koejäsenten D-arvot eivät tilastollisesti poikenneet toisistaan. Eri koejäsenten päiväkasvunopeudet vaihtelivat välillä $76-107 \mathrm{~kg}$ ka/ha/vrk ja $73-100$ ry ha/vrk. Koejäsen A:n päiväkohtainen kasvu oli paras. Jälkisadossa sadonmuodostuksen ja D-arvon välillä ei ollut yhteyttä.

Kolmannen niiton päiväkasvu jäi hyvin vaatimattomaksi 29 kg ka/ha/vrk. Sen D-arvo jouduttiin keskeneräisten laboratorioanalyysien vuoksi arvioimaan koostumuksen perusteella, joten tuloksiin täytyy suhtautua varauksella. Sato sisälsi paljon kuollutta materiaalia, mutta toisaalta NDF-pitoisuus oli varsin alhainen.

Eri systeemien kokonaissadot käyttäytyivät sikäli odotetusti, että 2 niiton systeemin kuiva-aine ja rehuyksikkösadot olivat suurempia kuin 3 niiton systeemin (esim. Pulli 1980; taulukko 2). Niiton myöhästyttäminen 1. sadossa lisäsi kokonaiskuiva-ainesatoa noin $1000 \mathrm{~kg} / \mathrm{ha}$, mutta rehuyksikkösato ei lisääntynyt samassa suhteessa. Toisen niiton ajoitus ei vaikuttanut yhtä merkittävästi kokonaissatoon (taulukko 1. ruutukoesadot; taulukko 3. maatilamittakaava). 
Taulukko 1. Eri korjuustrategioiden satotulokset ruutukokeesta niitoittain 2009.

\begin{tabular}{|c|c|c|c|c|c|c|c|c|c|c|c|}
\hline $\begin{array}{l}\text { Koe- } \\
\text { jäsen }\end{array}$ & Niitto & $\begin{array}{c}\text { Niitto- } \\
\text { pv. }\end{array}$ & $\mathrm{Ka}$ & Sato & ry-sato & D-arvo & RV & NDF & Kuollut & $\begin{array}{c}\text { Korsien } \\
\text { osuus }\end{array}$ & $\begin{array}{l}\text { Kukinto- } \\
\text { jen osuus }\end{array}$ \\
\hline & & & $\%$ & kg ka/ha & ry/ha & g/kg ka & g/kg ka & $\mathrm{g} / \mathrm{kg} \mathrm{ka}$ & $\%$ & $\%$ & $\%$ \\
\hline A & 1 & 17.6. & $15,0 \mathrm{a}$ & 2930a & $2835 a$ & $708 a$ & $179 a$ & $583 a$ & $0 \mathrm{a}$ & $49 a$ & $2 a$ \\
\hline B & 1 & 26.6 . & $18,5 \mathrm{c}$ & $5050 \mathrm{c}$ & $4512 c$ & $653 c$ & $125 c$ & $656 c$ & $0 \mathrm{a}$ & $60 c$ & $8 b$ \\
\hline $\mathrm{C}$ & 1 & 2.7 & $22,7 b$ & 6160b & $5125 b$ & $608 b$ & $113 b$ & $643 b$ & $2 b$ & $65 b$ & $9 b$ \\
\hline $\mathrm{D}$ & 1 & 17.6. & $15,4 a$ & 3010a & $2905 a$ & $707 a$ & $169 a$ & $585 a$ & 0a & $51 \mathrm{a}$ & $1 \mathrm{a}$ \\
\hline SEM & & & 0,30 & 89 & 100,1 & 4,5 & 3,0 & 3,9 & 1) & 1,5 & 0,3 \\
\hline P-arvo & & & $<0,001$ & $<0,001$ & $<0,001$ & $<0,001$ & $<0,001$ & $<0,001$ & $<0,001$ & $<0,001$ & $<0,001$ \\
\hline$A$ & 2 & 10.8 . & $30,5 b$ & $5800 c$ & $5404 c$ & 682 & $103 b$ & $556 a b$ & $12 b$ & $37 a$ & 0 \\
\hline B & 2 & 19.8. & $20,5 a$ & 4380b & 4060b & 678 & $121 \mathrm{c}$ & 562ab & $14 \mathrm{~b}$ & $45 a$ & 0 \\
\hline $\mathrm{C}$ & 2 & 19.8. & $21,9 a$ & $3650 a b$ & 3515ab & 704 & 131c & $547 b$ & $14 \mathrm{~b}$ & $26 b$ & 0 \\
\hline D & 2 & 27.7. & 21,9a & $3460 a$ & $3215 a$ & 679 & $155 a$ & 573a & $4 a$ & $35 a b$ & 0 \\
\hline SEM & & & 1,08 & 212 & 177,3 & 7,6 & 4,5 & 9,0 & 1) & 3,4 & 0,2 \\
\hline P-arvo & & & $<0,001$ & $<0,001$ & $<0,001$ & 0,082 & $<0,001$ & 0,031 & $<0,001$ & 0,040 & 0,36 \\
\hline $\mathrm{D}$ & 3 & 8.10. & 25,6 & 2102 & 1814 & 631 & . & 462 & 18 & 11 & 0 \\
\hline SEM & & & & 202 & 174,0 &. & . & 5,1 & 0,6 & 2,5 & . \\
\hline
\end{tabular}

A= Tavanomainen säilörehunkorjuu kahdella niitolla, ensimmäisen niiton D-arvotavoite $690 \mathrm{~g} / \mathrm{kg}$ ka, B= kesäkuun loppuun myöhästetty rehunkorjuu kohdella niitolla, ensimmäisen niiton D-arvotavoite $650 \mathrm{~g} / \mathrm{kg} \mathrm{ka}, \mathrm{C}=$ Heinäkuun alkuun myöhästetty niitto, ensimmäisen niiton D-arvotavoite 620 g/kg ka, D= Kolmen niittokerran säilörehunkorjuu, jossa ensimmäinen niitto, kun säilörehun D-arvo 690 g/kg ka, toinen rehunkorjuu aivan heinäkuun lopussa ja viimeinen lokakuun alussa. Mikäli saman sarakkeen luvut on merkitty samalla kirjaimella, ne eivät eroa toisistaan (Tukey'n testi $\mathrm{p}>0$,05). D-arvot laskettu Artturi ${ }^{\circledR}$-verkkopalvelun voimassa olevalla laskurilla (Artturi 2009). Kolmannen niiton D-arvo estimoitu kuolleen solukon ja lehtien osuuden perusteella; kemialliset analyysit vielä valmistumatta. SEM=keskivirhe. ${ }^{1)}$ Ei SEM-arvoa, koska käytetty ln (x) -muunnosta.

Taulukko 2. Eri korjuustrategioiden kokonaissadot ruutukokeessa 2009.

\begin{tabular}{lll} 
Koejäsen & \multicolumn{2}{l}{ Kokonaissato } \\
\hline & $\mathrm{kg} \mathrm{ka} / \mathrm{ha}$ & $\mathrm{ry} / \mathrm{ha}$ \\
\hline $\mathrm{A}$ & $8730 \mathrm{a}$ & 8239 \\
$\mathrm{~B}$ & $9430 \mathrm{~b}$ & 8572 \\
$\mathrm{C}$ & $9820 \mathrm{~b}$ & 8640 \\
D & $8570 \mathrm{a}$ & 7934 \\
\hline SEM & 245 & 215 \\
P-arvo & 0,014 & 0,12 \\
\hline
\end{tabular}

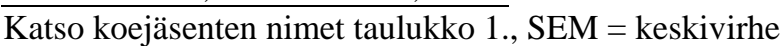

Taulukko 3. Eri korjuustrategioiden kokonaissadot maatilamittakaavassa 2009.

\begin{tabular}{lcccc} 
Koejäsen & Niitto 1 & Niitto 2 & Niitto 3 & Yhteensä \\
\hline A & $\mathrm{kg} \mathrm{ka} / \mathrm{ha}$ & $\mathrm{kg} \mathrm{ka} / \mathrm{ha}$ & $\mathrm{kg} \mathrm{ka} / \mathrm{ha}$ & $\mathrm{kg} \mathrm{ka} / \mathrm{ha}$ \\
$\mathrm{B}$ & 4975 & 3956 & & 8930 \\
$\mathrm{C}$ & 6119 & 3057 & & 9176 \\
$\mathrm{D}$ & 6391 & 3686 & & 10077 \\
Apila B & 4609 & 2860 & 2004 & 9473 \\
Apila C & 6265 & 3058 & & 9323 \\
\hline
\end{tabular}

Katso koejäsenten nimet taulukko 1.

\section{Ruokintakoe}

Ruokintakoe suoritettiin kesällä 2008 tehdystä rehusta. Kesäkuun loppu oli melko viileä ja sateinen. Näissä olosuhteissa nurmen D-arvo pysyi pitkään korkealla ja heinäkuun alussa korjatun säilörehun Darvo jäi tavoitteeseen nähden korkeammalle. Tavoitteena oli saada tuotantokokeeseen mukaan Darvoltaan 600-620 g/kg ka säilörehua. Salvosiiloissa varastoitujen rehujen käymislaadussa ei ollut 
huomautettavaa ja rehut olivat myös aistinvaraisesti arvioituna hyvin tavanomaisia. Rehujen $\mathrm{pH}$ vaihteli välillä 3,8 - 4,1, liukoinen typpi välillä 10 - 14 g/kg ka ja haihtuvat rasvahapot välillä 16-19 g/kg ka.

Maidontuotantokokeessa tarkasteltiin väkirehumäärän ja väkirehun valkuaispitoisuuden tuotosvastetta sulavuudeltaan erilaisten säilörehujen kanssa (taulukko 3 ja 4). Säilörehun sulavuuden nousu lisäsi energiakorjattua maidontuotantoa $0,48 \mathrm{~kg}$, mitä voidaan pitää kohtuullisen hyvänä vasteena (Kuoppala ym. 2008). Hyvä tuotosvaste selittyy säilörehun syönnillä. D-arvoltaan $690 \mathrm{~g} / \mathrm{kg}$ ka rehua syötiin 2,4 rehuyksikköä enemmän verrattuna heikommin sulavaan säilörehuun. Maitotuotosero erilaisten säilörehujen välillä saatiin kurottua kiinni 3 kilon väkirehumäärällä. Numeroarvoisesti väkirehulisästä oli enemmän hyötyä D-arvoltaan $650 \mathrm{~g} / \mathrm{kg}$ ka rehulla verrattuna D-arvoltaan $690 \mathrm{~g} / \mathrm{kg}$ ka rehuun. Yhdysvaikutus ei kuitenkaan ollut merkitsevä. Aikaisempien koetulosten perusteella väkirehuvaste on lisääntynyt säilörehun sulavuuden alentuessa (Rinne, 2000), vaikkei kuitenkaan aina (Rinne ym. 1999).

Säilörehun sulavuuden alentuessa pötsimikrobeiden energiansaanti heikkenee ja mikrobivalkuaisen tuotanto alkaa rajoittaa maidontuotantoa. Tällaisessa tilanteessa väkirehun lisävalkuaisella voisi odottaa olevan hyvä vaste nimenomaan matalan D-arvon säilörehulla. Taulukon 4 mukaan tällaista säilörehun sulavuuden ja väkirehun valkuaispitoisuuden -yhdysvaikutusta ei ollut. Säilörehun matalaa sulavuutta ei voida täysin kompensoida väkirehun lisävalkuaisella. Tällöin tuotosta rajoittava tekijä on ennemminkin energia kuin valkuainen. Lisävalkuaisen keskimääräinen vaste oli 0,3 kg EKM / 1 \% väkirehun raakavalkuaista.

Taulukko 4. Säilörehun D-arvon ja väkirehulisäyksen vaikutus maitotuotokseen ja rehujen syöntiin.

\begin{tabular}{lcccccccc}
\hline & \multicolumn{2}{c}{ D-arvo 650 g/kg ka } & \multicolumn{2}{c}{ D-arvo 690 g/kg ka } & \multicolumn{4}{c}{ Merkitsevyystaso } \\
& $9 \mathrm{~kg}$ & $12 \mathrm{~kg}$ & $9 \mathrm{~kg}$ & $12 \mathrm{~kg}$ & $\mathrm{SEM}$ & D-arvo & Väkirehu & $\mathrm{D}^{*}$ väkirehu \\
\hline Maito kg/pv & 27,1 & 29,6 & 29,5 & 31,6 & 0,65 & 0,001 & 0,001 & $>0,2$ \\
EKM kg/pv & 28,0 & 30,5 & 30,6 & 32,7 & 0,6 & 0,001 & 0,001 & $>0,2$ \\
Rasva g/kg & 43,3 & 42,7 & 43,3 & 43,0 & 0,89 & $>0,2$ & $>0,2$ & $>0,2$ \\
Valkuainen g/kg & 34,9 & 35,6 & 35,0 & 35,1 & 0,49 & $>0,2$ & 0,09 & $>0,2$ \\
Urea mg/dl & 26 & 27 & 27 & 29 & 0,8 & 0,003 & 0,006 & $>0,2$ \\
Säilörehunsyönti kg ka/pv & 12,7 & 12,0 & 14,5 & 13,5 & 0,33 & 0,001 & 0,001 & $>0,2$ \\
Kuiva-ainesyönti kg/pv & 20,6 & 22,6 & 22,5 & 24,1 & 0,33 & 0,001 & 0,001 & $>0,2$ \\
\hline
\end{tabular}

EKM=energiakorjattumaitomäärä, SEM= keskivirhe

Taulukko 5. Väkirehun valkuaispitoisuuden vaikutus maitotuotokseen ja rehujen syöntiin.

\begin{tabular}{lccccccccc}
\hline & \multicolumn{3}{c}{ D-arvo 650 g/kg ka } & \multicolumn{3}{c}{ D-arvo 690 g/kg ka } & \multicolumn{3}{c}{ Merkitsevyystaso } \\
& RV 14 & RV 17 & RV 21 & RV 14 & RV 17 & RV 21 & SEM & Valk lin & Valk*Darvo \\
\hline Maito kg/pv & 27,5 & 28,7 & 28,8 & 29,4 & 30,6 & 31,7 & 0,68 & 0,001 & $>0,2$ \\
EKM kg/pv & 28,3 & 29,7 & 29,7 & 30,0 & 31,9 & 32,9 & 0,63 & 0,001 & $>0,2$ \\
Rasva g/kg & 43,2 & 42,7 & 42,8 & 43,4 & 43,3 & 42,8 & 0,93 & $>0,2$ & $>0,2$ \\
Valkuainen g/kg & 34,9 & 35,3 & 35,7 & 34,9 & 35,3 & 35,0 & 0,51 & 0,13 & $>0,2$ \\
Urea, mg/dl & 21 & 28 & 32 & 23 & 29 & 33 & 0,9 & $<0,001$ & $>0,2$ \\
Säilörehunsyönti & & & & & & & & & \\
kg ka/pv & 11,9 & 12,5 & 12,7 & 13,7 & 13,9 & 14,4 & 0,33 & 0,007 & $>0,2$ \\
Kuiva-ainesyönti kg/pv & 20,7 & 22,6 & 22,5 & 23,0 & 23,2 & 23,7 & 0,34 & 0,008 & $>0,2$ \\
\hline
\end{tabular}

EKM=energiakorjattumaitomäärä, SEM=keskivirhe

Tämän kokeen tulokset kattavat vain pienen osan kaikista maatilan rehunkorjuuvaihtoehdoista. Säilörehun D-arvon muutoksista johtuvat tuotosvasteet ovat erilaiset nurmen ensi- ja jälkikasvussa. Väkirehuvaste on myös erilainen erityyppisillä säilörehuilla. Kokeen tulokset täydentyvät kolmevuotisen KARPE-hankkeen aikana siten, että mukaan tulee mahdollisimman kattavasti eri korjuuaikayhdistelmävaihtoehtoja. Aikaisemman koetoiminnan ja hankkeen tulokset hyödynnetään maidontuotantomallin rakentamisessa. Maidontuotantomalli yhdistettynä nurmen kasvumalliin antaa pohjan kattavalle taloudelliselle tarkastelulle. 


\section{Johtopäätökset}

Säilörehun ensimmäisen korjuuajan myöhästyttäminen lisäsi kokonaissadossa sekä kuiva-aine-, että rehuyksikkömäärää. Ensimmäisessä sadossa saavutettu lisäkasvu kuitenkin kompensoitui osittain toisessa sadossa, joten erot eri niittostrategioiden välillä eivät muodostuneet mittaviksi. Rehuyksikköarvo huomioiden erot eri niittostrategioiden välillä vielä pienenivät. Kolmen niiton strategialla kokonaissato jäi pienimmäksi. Jälkisadon D-arvoihin ensimmäisen niiton ajoituksella ei ollut merkittävää vaikutusta. Ruutukokeen perusteella myöhäisin ensimmäinen niitto olisi paras vaihtoehto.

Ruokintakokeen perusteella 3 kg väkirehua vastasi 4 prosenttiyksikön muutosta D-arvossa. Suurin maitotuotos saavutettiin D-arvoltaan 690 g/kg ka säilörehulla ja korkeimmalla väkirehutasolla. Koeasetelma ei ota kantaa siihen, miten korkea väkirehumäärä D-arvoltaan 650 g/kg ka säilörehulla tarvittaisiin, jotta päästäisiin samaan tuotostasoon D-arvoltaan 690 g/kg ka ja 12 kilon väkirehuyhdistelmän kanssa. Tämän kokeen perusteella väkirehussa voidaan käyttää samaa valkuaispitoisuutta ainakin, kun D-arvo on 650 - 690 g/kg ka välillä. Suurin maitotuotos saadaan korkeimmalla valkuaistasolla. Tämän kokeen perusteella ei voida vielä valita niittoaikastrategioista kannattavinta, koska valinta riippuu tuotantopanosten ja maidon hintasuhteista. Tutkimuksen jatkuessa tähän voidaan paremmin vastata.

\section{Kirjallisuus}

Artturi. 2009. ARTTURI® ${ }^{\circledR}$-verkkopalvelu. Viitattu 8.12.2009

https://portal.mtt.fi/portal/page/portal/Artturi/Artturikirjasto/Laskurit/Sulavuuslaskuri_2007.xls

Kuoppala, K., Rinne M., Nousiainen J., Huhtanen P. 2008. The effect of cutting time of grass silage in primarygrowth and regrowth and the interactions between silage quality and concentrate level on milk production of dairy cows.

ProRehustus tuotosseuranta Saatavilla: http://www.proagria.fi/palvelut/maito/maito.asp?cat=prorehustus. Viitattu 27.11.2009.

Pulli, S. 1980. Growth factors and management technique used in relation to the developmental rhythm and yield formation pattern of a pure grass stand. Journal of the Scientific Agricultural Society of Finland 52: 281330.

Rinne, M. 2000. Influence of the timing of the harvest of primary grass growth on herbage quality and subsequent digestion and performance in the ruminant animal. University of Helsinki, Department of Animal Science. Publications 54. 42 p. +5 encl. Academic dissertation. Available at:

http://ethesis.helsinki.fi/julkaisut/maa/kotie/vk/rinne.

Rinne M., Jaakkola S., Kaustell K., Heikkilä T., \& Huhtanen P. 1999. Silages harvested at different stages of grass growth $v$. concentrate foods as energy and protein sources in milk production. Animal Science, 69:251263.

Simon, U. \& Park, B.H. 1981. A descriptive scheme for stages of development in perennial forage grasses. In: Smith, J.A. \& Hays, V.W., (Eds.), Proceedings of the XIV International Grassland Congress at Lexington, Kentucky, USA, June 15-24, 1981, pp. 416- 418.

Wathén A., Rinne M. \& Heikkilä A-M. 2008. Optimaalisesti rehua ja maitoa. Julkaisussa: Maataloustieteen Päivät 2008 [verkkojulkaisu]. Suomen Maataloustieteellisen Seuran tiedotteita no 23. Toim. Anneli Hopponen. Viitattu [16.11.2009]. Julkaistu 9.1.2008. Saatavilla Internetissä:

http://www.smts.fi/mpol2008/index_tiedostot/Esitelmat/es073.pdf 